\title{
Human Resource Management: A report on recent trends and practices
}

\section{Anna Gordon}

\author{
March, 2021
}

\section{Executive Summary}

The management of human resources is an integral part of the management function and is essential to the success of most organizations. We highlights recent trends in theory and practice, addressing major concerns related to human resources management and highlighting how new HRM concepts and approaches surpassed previous personnel procedures. Our analysis of the sector from the position of a non-specialist provides a vital evaluation of the human resources function and connects HRM and management practice and strategy. The management of human resources has beco me an integral part of the managing function of most companies and is essential for their success. In highlighting recent advances in theory and practice, we address the fundamental problems in the management of human resources and points out how new ideas and approaches have overcome past staff practices in HRM. Our analysis of the sector from the position of a non-specialist provides a vital evaluation of the human resources function and connects HRM and management practice and strategy.

In text citations:

[1][2] [3] [4] [5] [6][7] [8] [9] [10] [11] [12] [13] [14][15] [16] [17] [15] [18] [19][20] [21] [22] [16] [11]

\section{References:}

[1] S. E. Jackson, D. W. S. Renwick, C. J. C. Jabbour, and M. Muller-Camen, "State-of-the-art and future directions for green human resource management," Ger. J. Res. Hum. Resour. Manag., 2011.

[2] V. Benuyenah and P. B. Tran, "Postpartum psychological pressure on single mothers: an interpretative phenomenological analysis," J. Humanit. Appl. Soc. Sci. , 2020.

[3] D. E. Guest, "Human resource management and performance: A review and research agenda," Int. J. Hum. Resour. Manag., 1997.

[4] M. P. Markoulli, C. I. S. G. Lee, E. Byington, and W. A. Felps, "Mapping Human Resource Management: Reviewing the field and charting future directions," Hum. Resour. Manag. Rev., 
2017.

[5] V. Benuyenah, "Economics of Social Proximity-Measuring the Deadweight Loss of Tet Gifts."

[6] A. C. F. Kwok, "The Evolution of Management Theories: A Literature Review," Nang Yan Bus. J., 2018.

[7] M. Banai, "Strategy and human resource management," Int. J. Hum. Resour. Manag., 1992.

[8] R. J. Stone, Human Resource Management : Personnel Human Resource Management. 2019.

[9] V. Benuyenah and M. Phoon, "POPULATION, PROPERTY AND PRODUCTIVITY: A THEORETICAL PREDICTION OF ECONOMIC GROWTH IN VIETNAM.," J. Glob. Bus. Econ., vol. 8, no. 1, 2014.

[10] S. E. Jackson, R. S. Schuler, and K. Jiang, "An Aspirational Framework for Strategic Human Resource Management," Acad. Manag. Ann., 2014.

[11] P. M. Wright and S. A. Snell, "Toward a unifying framework for exploring fit and flexibility in strategichuman resource management," Acad. Manag. Rev., 1998.

[12] V. Benuyenah and B. Pandya, "Measuring employee happiness in the UAE-integrating organisational data into the national statistics," Int. Rev. Manag. Mark., vol. 10, no. 3, pp. 83-92, 2020.

[13] C. Guo and A. Al Ariss, "Human resource management of international migrants: current theories and future research," International Journal of Human Resource Management. 2015.

[14] M. L. Lengnick-Hall, C. A. Lengnick-Hall, L. S. Andrade, and B. Drake, "Strategichuman resource management: The evolution of the field," Hum. Resour. Manag. Rev. , 2009.

[15] M. R. Greenwood, "Ethics and HRM: A review and conceptual analysis," Journal of Business Ethics. 2002.

[16] V. Benuyenah, "Theorising an organisational citizenship behaviour model for managerial decision-making: from history to contemporary application," Manag. Res. Rev., 2021.

[17] S. Strohmeier, "Research in e-HRM: Review and implications," Hum. Resour. Manag. Rev., 2007.

[18] D. W. S. Renwick, C. J. C. Jabbour, M. Muller-Camen, T. Redman, and A. Wilkinson, "Contemporary developments in Green (environmental) HRMscholarship," Int. J. Hum. Resour. Manag., 2016.

[19] A. Salehi, "Strategic human resource management," Adv. Environ. Biol., 2013.

[20] P. Thompson, "The trouble with HRM," Hum. Resour. Manag. J., 2011.

[21] V. Benuyenah and B. Boukareva, "Making HRM curriculum relevant-a hypothetical practitioners' guide,"J. Work. Manag., 2018.

[22] V. Benuyenah, "Conflict perspectives in international business organisations: The changing trends and its management," Manag. Leadersh. Gov., p. 417, 2013. 